\title{
Performance Evaluation of Four Stroke SI Engine with and without Oxyrich Air Energizer at 1000rpm
}

\author{
Nilesh T. Dhokane ${ }^{+*}$, Anand R. Nadgire ${ }^{\dagger}$ and Savita U. Shinde ${ }^{\dagger}$ \\ ${ }^{\dagger}$ Department of Mechanical Engineering, MIT College of Engineering, Savitribai Phule Pune University, Pune, India
}

Accepted 03 March 2016, Available online 15 March 2016, Special Issue-4 (March 2016)

\begin{abstract}
All the researchers have done study of engine performance parameters with addition of $\mathrm{H}_{2}$ or $\mathrm{O}_{2}$ and with turbocharger \& supercharger. I have done experimentation on intake side development of SI engine. No any research should be done on injecting the oxyrich air into intake manifold by using pure oxygen. So this research to improve the performance of SI engine \& reduces the amount of fuel consumption \& due to complete combustion the pollution of SI engine is also reduced. Therefore the research may be done on oxyrich air for combustion of fuel in SI engine. Here I have found brake specific fuel consumption with and without oxyrich air energizer, determined brake thermal efficiency of the system. Also I have checked all emission parameters of SI engine with and without oxyrich air energizer. I could find Mechanical \& Volumetric efficiency of engine with and without oxygen blending. For developing the experimental set up for oxyrich air energizer, I used computerized MPFI 4 stroke petrol engine test rig.
\end{abstract}

Keywords: Oxyrich air energizer, Specific fuel consumption, Thermal efficiency, 4 stroke petrol engine.

\section{Introduction}

A simple pair of magnets which is used to magnetize the incoming air is called as air energizer. It is installed on intake manifold pipe as well as air intake pipe. After installation of magnets on pipes it creates magnetic field which magnetizes the paramagnetic oxygen in air. This helps to improve combustion in engine. It gives extra mileage and power of I.C. Engine. It ensures minimum deposition of carbon on the spark plug and on the engine piston head improves compression capacity of the piston helping in the reduction in noise and vibration.

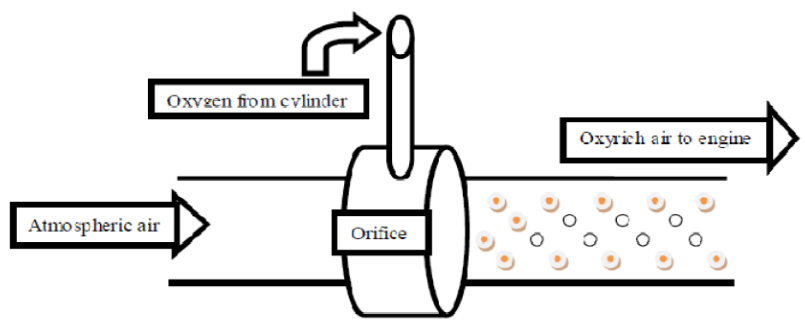

Fig.1 Working principal of Oxyrich Apparatus

The application of oxyrich air converts fuel molecules to a positive charge and sets them in order, which increases the attraction of negatively charged air molecules, boosted by the charged air to compensate for the improper fuel/air mixture. It is placed in automotive vehicles on the air duct before the air filter to allow for the optimum combustion and further reduction of toxic substances. This significantly improves the process of oxidation. As a result the corrosion and scale deposits are dissolved and the new ones do not form in the whole cooling system, engine gets back $100 \%$ of its heat transfer ability and can be exploited longer.

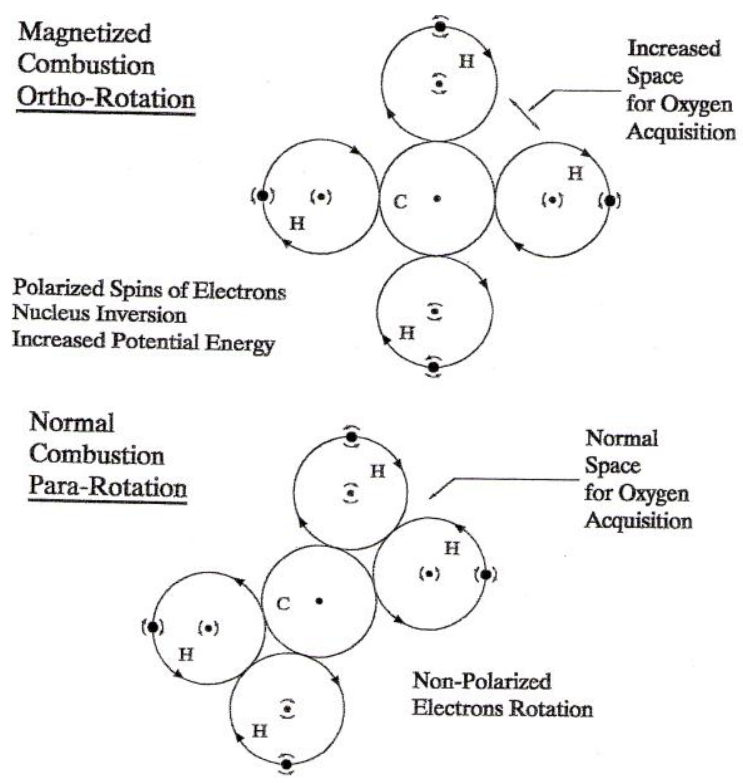

Fig.2 Oxygenated combustion reaction 
Whenever this system is placed on gaseous hydrocarbon fuels like gasoline the air/fuel mixture becomes rich mixture and must be adjusted. Generally, air supply need to be increased for stoichiometric balance. Air energizer is a fully permanent device. It can easily be transferred from car to car, with almost no labor. These units have low cost as compare to the catalytic converter system. The unit is totally ecofriendly.

\section{System Development}

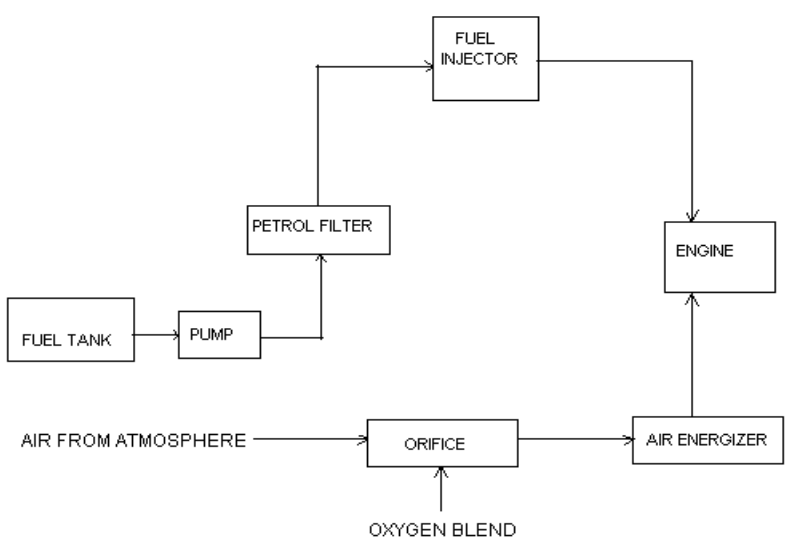

Fig.3 Layout of Experimental Set-up

Fig.3 shows schematic diagram, where the one side of the engine is fuel line \& other side is air line. Air from the atmospheric come into orifice \& the pure oxygen is injected into that air in orifice. The effect of oxygen blend is to increase the amount of oxygen in air. After that the magnets are placed over the air line for magnetizing the air. The segment and circular type permanent magnet is used for magnetizing the air. Simultaneously all the performance parameters are to be measured by using computerized test rig of 4 stroke petrol engine and pollution of system will be measured by using exhaust gas analyzer and compared it with and without oxyrich air energizer.

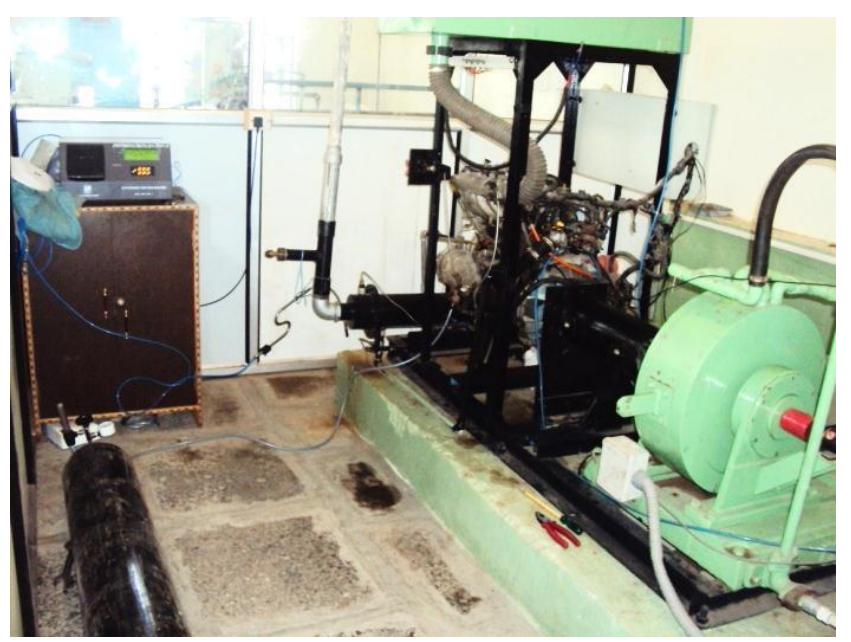

Fig.4 Actual Experimental set-up
Fig.4 shows actual experimental set up. It consist of engine test rig, oxygen cylinder, flow meter, magnets, eddy current dynamometer, computer , EPA software, Digital indicator, Exhaust gas analyzer etc.

MPFI 4 stroke petrol engine:-TATA make engine with capacity 1405 cc rpm and rated Power 63.5 bhp @ 5000. Torque- 110 N.m @ 3000 rpm. Bore -75 mm Stroke $-79.50 \mathrm{~mm}$, Connecting Rod Length $-145 \mathrm{~mm}$, compression atio is 9.5: 1. 4 Stroke, 4 Cylinder, MPFI Water cooled, Petrol engine

Permanent industrial magnet: With origin Zhejiang, China (Mainland) and shape Segment type / circular type. Composite: NdFeB Magnet, Brand name: Bestway, Function: To save fuel \& reduce emission gases, Strength: 1 Tesla

\section{Observations}

Initially observations are taken without oxyrich air energizer at different speeds, for comparison.

Table 1 Without oxyrich air energizer speed 1000 rpm

\begin{tabular}{|c|c|c|c|c|c|c|}
\hline Parameter & Symbol & Unit & Load 1 & Load 2 & Load 3 & Load 4 \\
\hline Torque & $\mathrm{T}$ & $\mathrm{Nm}$ & 20.30 & 40.30 & 60.00 & 80.70 \\
\hline Speed & $\mathrm{N}$ & RPM & 833.0 & 785.0 & 767.2 & 764. \\
\hline Calorific Value of Fuel & $\mathrm{Cf}$ & $\mathrm{KJ} / \mathrm{kg}$ & 47300 & 47300 & 47300 & 47300 \\
\hline Fuel Sample Quantity & $V_{f}$ & g & 50.00 & 50.00 & 50.00 & 50.00 \\
\hline $\begin{array}{l}\text { Time for Fuel } \\
\text { Consumption }\end{array}$ & $\mathrm{T}_{\mathrm{f}}$ & Sec & 150.00 & 142.0 & 135.0 & 125.00 \\
\hline $\begin{array}{l}\text { Indicated mean } \\
\text { effective pressure }\end{array}$ & $P_{i}$ & bar & 2.30 & 2.76 & 3.44 & 4.09 \\
\hline $\begin{array}{l}\text { Volume of air intake } \\
\text { per minute }\end{array}$ & Qair & $\begin{array}{l}\mathrm{m}^{3} \\
/ \mathrm{min}\end{array}$ & 0.57 & 0.58 & 0.58 & 0.61 \\
\hline $\begin{array}{l}\text { Volume displaced per } \\
\text { minute by piston }\end{array}$ & $\mathrm{V}_{\mathrm{e}}$ & $\begin{array}{l}\mathrm{m}^{3} \\
/ \mathrm{min}\end{array}$ & 0.59 & 0.55 & 0.54 & 0.56 \\
\hline \multirow[t]{6}{*}{ Exhaust Gas Analysis } & $\mathrm{CO}$ & $\%$ & 11.26 & 9.633 & 9.244 & 9.170 \\
\hline & $\mathrm{HC}$ & PPM & 199 & 356 & 366 & 372 \\
\hline & $\mathrm{CO}_{2}$ & $\%$ & 19.60 & 20.50 & 19.50 & 19.70 \\
\hline & $\mathrm{O}_{2}$ & $\%$ & 3.52 & 3.66 & 4.13 & 4.25 \\
\hline & $\mathrm{NO}_{\mathrm{X}}$ & PPM & 177 & 182 & 188 & 203 \\
\hline & LDA & & 0.906 & 0.934 & 0.945 & 0.952 \\
\hline
\end{tabular}

Table 2 With oxygen at $5 \mathrm{lpm}$ and speed $1000 \mathrm{rpm}$

\begin{tabular}{|c|c|c|c|c|c|c|}
\hline Parameter & Symbol & Unit & Load 1 & Load 2 & Load 3 & Load 4 \\
\hline Torque & $\mathrm{T}$ & $\mathrm{N}-\mathrm{m}$ & 17.90 & 40.30 & 61.30 & 80.70 \\
\hline Speed & $\mathrm{N}$ & $\mathrm{RPM}$ & 871.44 & 824.87 & 768.05 & 758.69 \\
\hline Calorific Value of Fuel & $\mathrm{C}_{\mathrm{f}}$ & $\mathrm{KJ} / \mathrm{kg}$ & 47300 & 47300 & 47300 & 47300 \\
\hline Fuel Sample Quantity & $\mathrm{V}_{\mathrm{f}}$ & $\mathrm{Gram}$ & 50.00 & 50.00 & 50.00 & 50.00 \\
\hline Time for Fuel Consumption & $\mathrm{T}_{\mathrm{f}}$ & $\mathrm{Sec}$ & 172 & 158 & 148 & 140 \\
\hline Indicated mean effective pr & $\mathrm{P}_{\mathrm{i}}$ & $\mathrm{bar}$ & 1.88 & 2.62 & 3.33 & 4.02 \\
\hline $\begin{array}{c}\text { Volume of air intake per } \\
\text { minute }\end{array}$ & $\mathrm{Q}_{\text {air }}$ & $\mathrm{m}^{3} / \mathrm{min}$ & 0.60 & 0.58 & 0.58 & 0.60 \\
\hline
\end{tabular}




\begin{tabular}{|c|c|c|c|c|c|c|}
\hline $\begin{array}{c}\text { Volume displaced per } \\
\text { minute }\end{array}$ & $\mathrm{V}_{\mathrm{e}}$ & $\mathrm{m}^{3} / \mathrm{min}$ & 0.61 & 0.58 & 0.54 & 0.53 \\
\hline Exhaust Gas Analysis & $\mathrm{CO}$ & $\%$ & 4.420 & 4.361 & 3.664 & 2.334 \\
\hline & $\mathrm{HC}$ & $\mathrm{PPM}$ & 195 & 319 & 351 & 360 \\
\hline & $\mathrm{CO}_{2}$ & $\%$ & 15 & 18.30 & 19 & 20.60 \\
\hline & $\mathrm{O}_{2}$ & $\%$ & 8.44 & 6.41 & 6.53 & 5.52 \\
\hline & $\mathrm{NOx}$ & $\mathrm{PPM}$ & 185 & 192 & 198 & 212 \\
\hline & $\mathrm{LDA}$ & & 1.200 & 1.104 & 1.116 & 1.105 \\
\hline
\end{tabular}

Similar observations are made at oxygen supply of 10 lpm \& 15 lpm oxygen supply.

\section{Results and discussions}

For each observation made with or without oxyrich analyzer, only following parameters are considered for comparison. (given in Table 3)

Table 15 Parameters considered for comparison (Without oxyrich energizer speed $1000 \mathrm{rpm}$ )

\begin{tabular}{|c|c|c|c|c|c|c|}
\hline Parameter & Symbol & Unit & Load 1 & Load 2 & Load 3 & Load 4 \\
\hline Brake Power & B.P. & KW & 1.77 & 3.31 & 4.81 & 6.46 \\
\hline Indicated Power & I.P. & $\mathrm{KW}$ & 2.24 & 2.53 & 3.09 & 3.66 \\
\hline $\begin{array}{c}\text { Mechanical } \\
\text { Efficiency }\end{array}$ & $\eta \mathrm{m}$ & $\%$ & 78.90 & 130.50 & 155.92 & 176.39 \\
\hline $\begin{array}{c}\text { Brake Specific } \\
\text { Fuel } \\
\text { Consumption }\end{array}$ & $\mathrm{bsfc}$ & $\begin{array}{c}\mathrm{kg} / \mathrm{K} \\
\mathrm{W} \mathrm{hr}\end{array}$ & 0.68 & 0.38 & 0.28 & 0.22 \\
\hline $\begin{array}{c}\text { Brake Thermal } \\
\text { Efficiency }\end{array}$ & $\eta \mathrm{bt}$ & $\%$ & 11.23 & 19.88 & 27.50 & 34.15 \\
\hline $\begin{array}{c}\text { Volumetric } \\
\text { Efficiency }\end{array}$ & $\eta \mathrm{v}$ & $\%$ & 96.61 & 105.50 & 107.40 & 108.90 \\
\hline
\end{tabular}

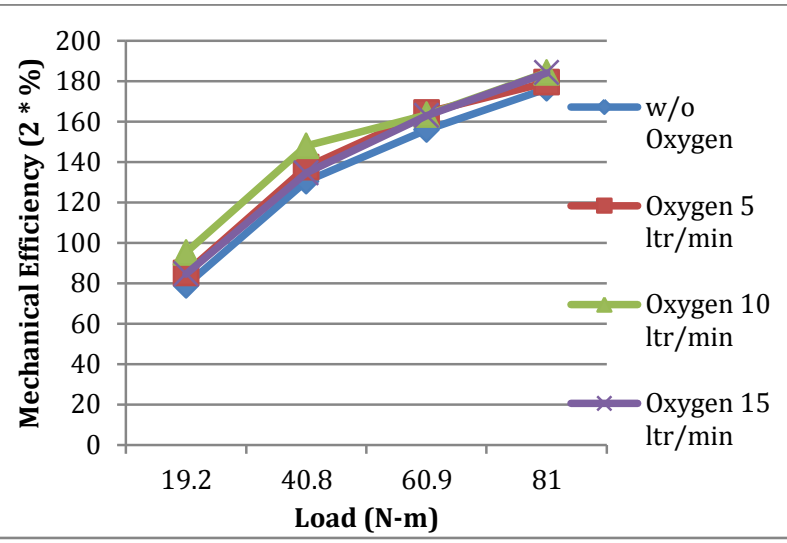

Fig.7 Mechanical efficiency vs Load at $1000 \mathrm{rpm}$

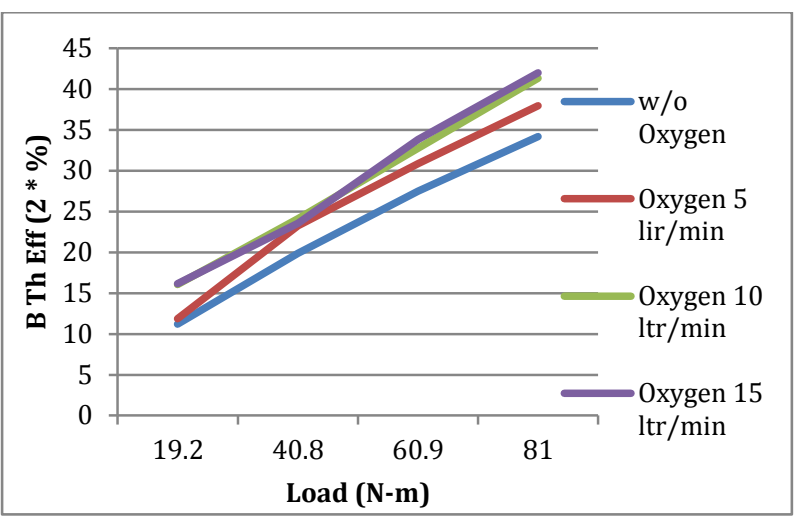

Fig.8 Brake Thermal Efficiency vs Load at $1000 \mathrm{rpm}$

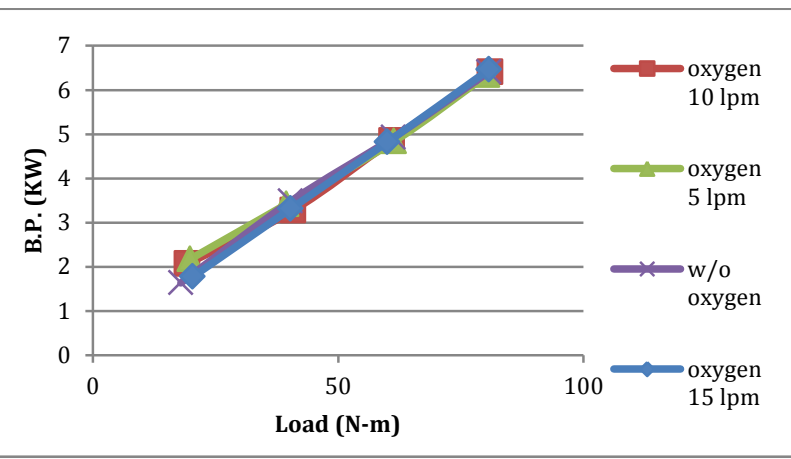

Fig.5 BP vs load at $1000 \mathrm{rpm}$

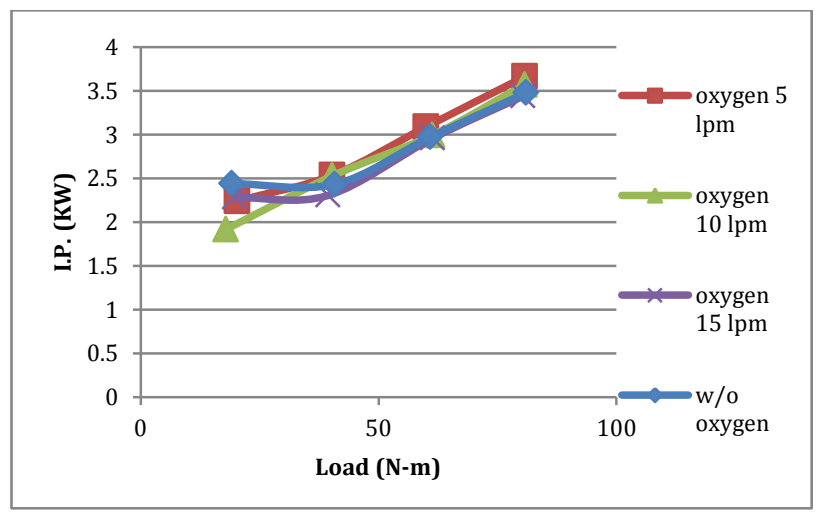

Fig.6 IP vs load at $1000 \mathrm{rpm}$

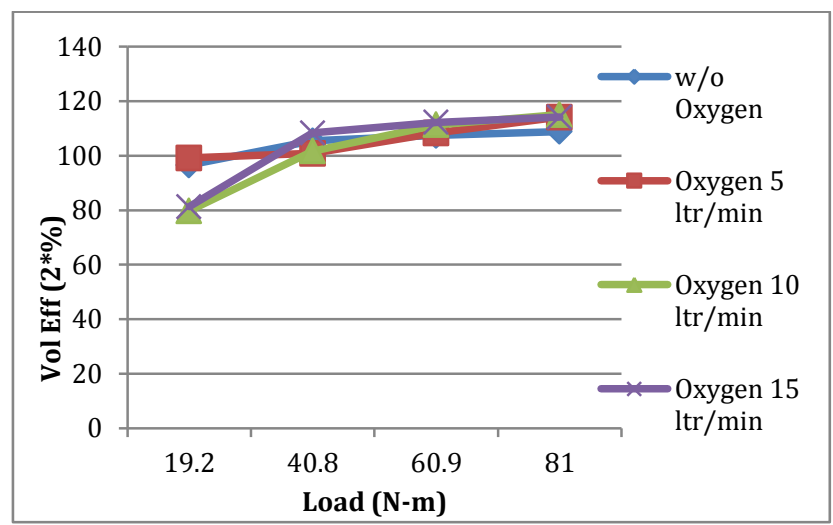

Fig.9 Volumetric Efficiency vs Load at 1000 rpm

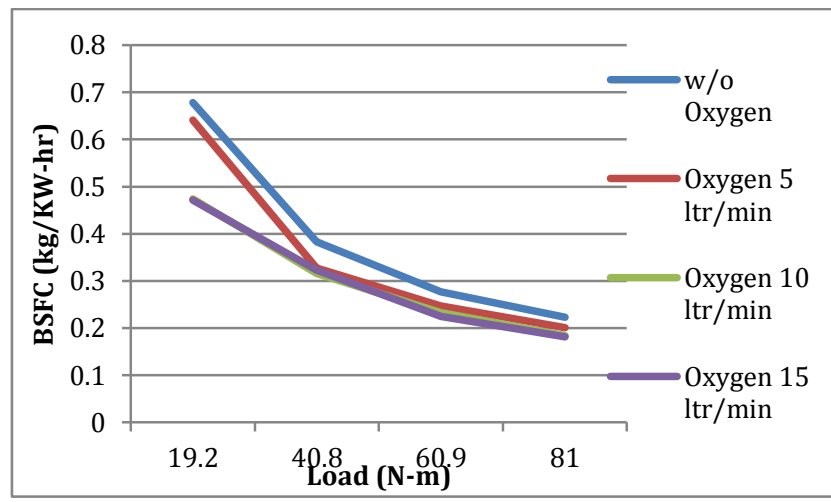

Fig.10 BSFC vs load at $1000 \mathrm{rpm}$ 


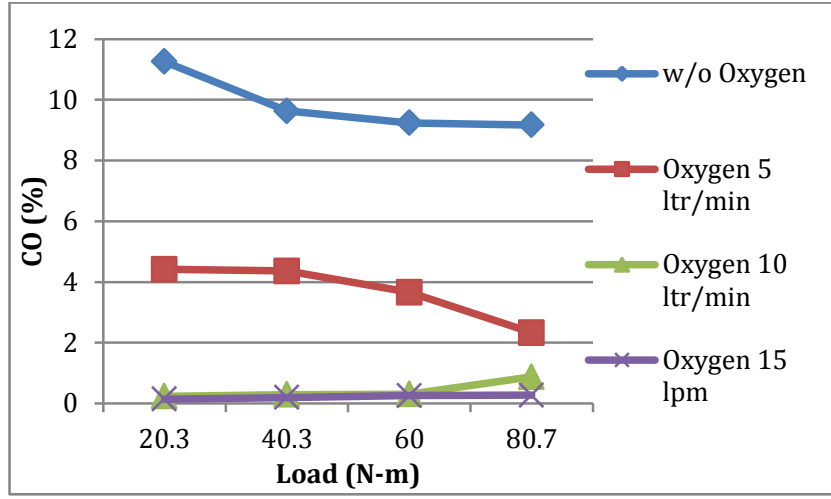

Fig.11 CO vs load at $1000 \mathrm{rpm}$

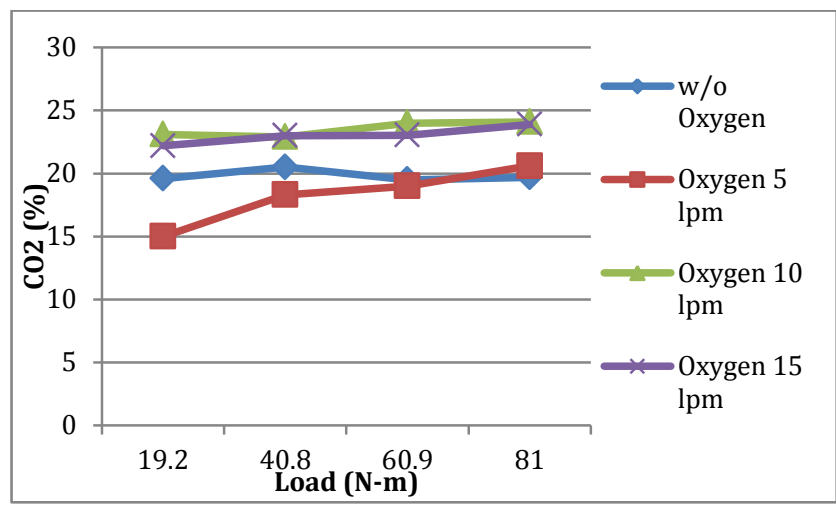

Fig.12 $\mathrm{CO}_{2}$ vs load at $1000 \mathrm{rpm}$

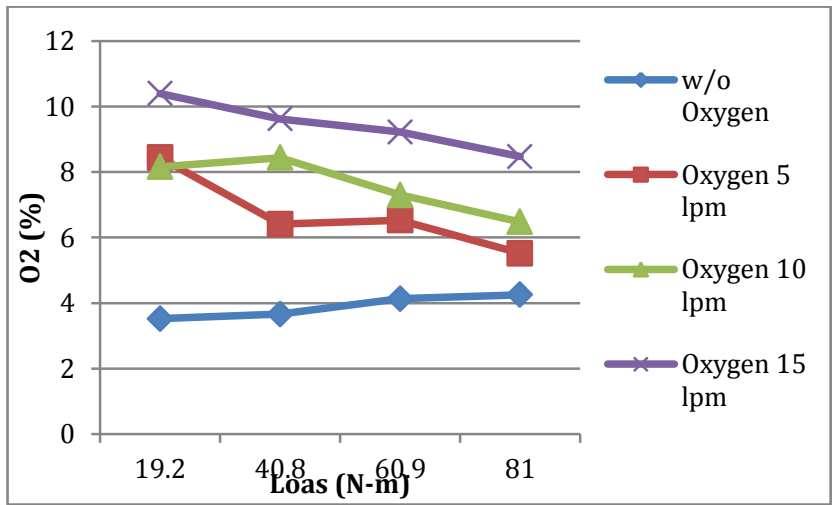

Fig.13 $\mathrm{O}_{2}$ vs load at $1000 \mathrm{rpm}$

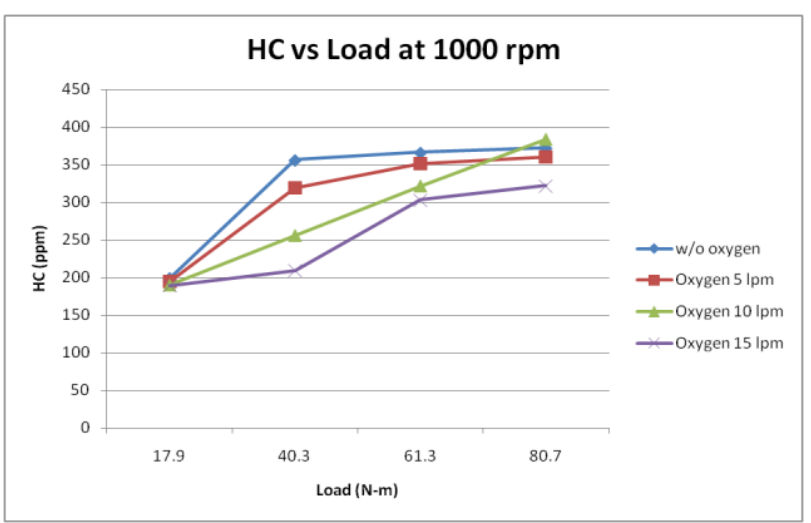

Fig.14 HC vs load at $1000 \mathrm{rpm}$

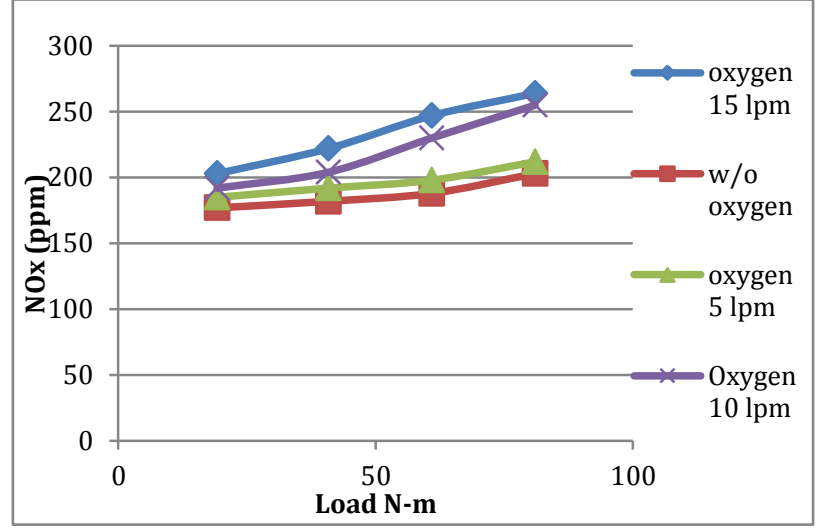

Fig.15 $\mathrm{NO}_{\mathrm{x}}$ vs load at $1000 \mathrm{rpm}$

Brake power gradually increases with increase in load and oxygen blend quantity. Indicated power gradually increases with increase in load. Not so many differences with respect to oxygen blend. Mechanical efficiency increases with increase in load and oxygen blend quantity. For $10 \mathrm{lpm}$ oxygen blend the Mechanical Efficiency increases maximum as compare to other. Brake Thermal Efficiency increases with increase in load and oxygen blend quantity.

\section{Conclusions}

The main objective of this experimentation is study effect of increasing the oxygen quantity in intake air on performance of 4-stroke petrol engine. The results indicates that the performance parameters of engine increases (10 - 25\%), the specific fuel consumption decreases (saving fuel up to $15 \%$ ) and the main pollutants of petrol engine ( $\mathrm{CO} \& \mathrm{HC}$ ) is also decreases. It helps to increase the engine life, reduces the running cost of engine and also reduces the air pollution which affects the human life.

- From all above results it is concluded that the Brake Power of 4-stroke petrol engine increases with increase in load and oxygen blend quantity.

- The Indicated Power of 4-stroke petrol engine gradually increases with increase in load, but decreases with increase in oxygen blend.

- Mechanical Efficiency of 4-stroke petrol engine increases with increase in load and oxygen blend quantity. For $10 \mathrm{lpm}$ oxygen blend the Mechanical Efficiency increases maximum (10-25\%) as compare to other.

- Brake Thermal Efficiency of 4-stroke petrol engine increases with increase in load and oxygen blend quantity. For $10 \mathrm{lpm}$ oxygen blend the Brake Thermal Efficiency increases maximum (10-25\%) as compare to other.

- Volumetric Efficiency of 4-stroke petrol engine slightly increases with increase in load and oxygen blend quantity. Because of small amount of oxygen blended in intake air not so many differences in Volumetric Efficiency of engine without and with oxyrich air energizer. 
- Because of oxyrich air the complete combustion of fuel should take place, therefore Brake Specific Fuel Consumption of 4-stroke engine decreases (upto 15\%) with increase in load and oxygen blend quantity. It also decreases the running cost of engine.

- The main pollutants of petrol engine is $\mathrm{CO}$ and $\mathrm{HC}$ which is harmful for human life, both are reduces only when the complete combustion of fuel should take place. It is done by increasing the oxygen quantity in intake air. In this method these both pollutants are reduced upto $20-30 \%$.

- The other pollutants of petrol engine are $\mathrm{CO}_{2}, \mathrm{O}_{2}$, $\mathrm{NO}_{\mathrm{x}}$ increases with increase in load and oxygen blend quantity.

- $\quad$ LDA in exhaust gas of 4-stroke petrol engine is also increases with increase in load, fuel supply and oxyrich air energizer.

- It is concluded that for $10 \mathrm{lpm}$ of oxygen blending in intake air, 4-stroke petrol engine getting better performance. More than $10 \mathrm{lpm}$ of oxygen gas increases the cost of oxygen and performance is same or below than performance for $10 \mathrm{lpm}$ oxygen blending.

\section{References}

T. Maxwell, V. Setty, J. Jones and R. Narayan (1993), The effect of oxygen enriched air on the performance and emissions of Internal Combustion Engines, Society of Automotive Engineers.

P. Anderson and L. Eriksson (2001), Air-to-Cylinder Observer on a Turbocharged SI-Engine with waste gate, Society of Automotive Engineers, Vol.01, pp.262-268.
C. Wu, P. Puzinauskas and J. Tsai (2003), Performance analysis and optimization of a supercharged Miller cycle Otto engine, Applied Thermal Engineering, Vol.23, pp.511521.

S. V. Saravanan (2006), Investigation of pollution monitoring and its control for the Indian petrol light duty vehicles applications to meet emission regulations, International Journal of Enviromedia, Vol.4, pp.821-826.

P. Govindasamy and S. Dhandapani (2007), An Experimental Investigation on the effect of Magnetic flux to reduce emissions and improve combustion performance in a fourstroke catalytic coated spark ignition engine, KSAE International Journal of Automotive Technology, Vol.8, 2006079.

M. Shehata and S. Razek (2008), Engine performance parameters and emissions reduction methods for spark ignition engine, Engineering Research Journal, Vol.120, M32 - M57.

A. Said, M. Mubin, S. Sulaiman and R. Shazi (2009), Experimental investigation of an air enhancement device on the performance of a spark ignition engine, The institution of engineers, Malaysia, Vol.72/3.

N. Killingsworth, V. Rapp, D. Flowers, S. Acevej, Y. Chen, and R. Dibble (2010), Increased Efficiency in SI Engine with Air Replaced by Oxygen in Argon Mixture, 33rd International Symposium on Combustion Beijing, China, pp.1-6.

J. Kirwan, M. Shost, G. Roth and J. Zizelman (2010), 3-Cylinder Turbocharged Gasoline Direct Injection: A High Value Solution for Low $\mathrm{CO} 2$ and NOx Emissions, Society of Automotive Engineers, Vol.01, 590.

C. Dahnz and U. Spicher (2010), Irregular combustion in supercharged spark ignition engines pre-ignition and other phenomena, International Journal of Engine Research, 485.

N. Hargude (2012, An experimental investigation for performance analysis of four stroke SI engine using oxyrich air, International Journal of Mechanical \& Engg. Technology, Vol.3(2), pp.532-542. 